\title{
Distribution modelling of wild rabbit hunting yields in its original area (S Iberian Peninsula)
}

\author{
M. Á. FARFÁN ${ }^{1}$, J. M. VARGAS ${ }^{2 *}$, J. C. GUERRERO ${ }^{1}$, A. M. BARBOSA ${ }^{2}$, J. DUARTE $^{1}$ \\ \& R. REAL ${ }^{2}$ \\ ${ }^{1}$ Biogea Consultores, Málaga, Spain, and ${ }^{2}$ Departamento de Biología Animal, Facultad de Ciencias, Universidad de \\ Málaga, Málaga, Spain
}

\begin{abstract}
In this work we used the information of the Annual Hunting Reports (AHRs) to obtain a high-resolution model of the potential favourableness for wild rabbit harvesting in Andalusia (southern Spain), using environmental and land-use variables as predictors. We analysed 32,134 AHRs from the period 1993/2001 reported by 6049 game estates to estimate the average hunting yields of wild rabbit in each Andalusian municipality $(n=771)$. We modelled the favourableness for obtaining good hunting yields using stepwise logistic regression on a set of climatic, orographical, land use, and vegetation variables. The favourability equation was used to create a downscaled image representing the favourableness of obtaining good hunting yields for the wild rabbit in $1 \times 1 \mathrm{~km}$ squares in Andalusia, using the Idrisi Image Calculator. The variables that affected hunting yields of wild rabbit were altitude, dry wood crops (mainly olive groves, almond groves, and vineyards), temperature, pasture, slope, and annual number of frost days. The $1 \times 1 \mathrm{~km}$ squares with high favourableness values are scattered throughout the territory, which seems to be caused mainly by the effect of vegetation. Finally, we obtained quality categories for the territory by combining the probability values given by logistic regression with those of the environmental favourability function.
\end{abstract}

Keywords: Andalusia, favourableness, game species, logistic regression, management plans, wild rabbit

\section{Introduction}

The European wild rabbit (Oryctolagus cuniculus Linnaeus 1758) is a lagomorph species native to the Iberian Peninsula. Its range expanded naturally to most of continental Europe, and the species has been widely introduced by man in other insular and continental areas throughout the world (Villafuerte et al. 1993; Monnerot et al. 1994; Homolka \& Zima 1999). It is a keystone species in the Iberian Mediterranean ecosystems, where it is the staple prey of at least 29 species of predators (Delibes \& Hiraldo 1981), among them the Iberian lynx (Lynx pardinus) and the Spanish Imperial Eagle (Aquila adalberti), which are endemic to the Iberian Peninsula and included among the most threatened species in the world (Delibes et al. 2000; Ferrer 2001). Rabbits occur throughout the Iberian Peninsula, except in mountainous areas over $1500 \mathrm{~m}$ (Flux 1994; Villafuerte 2002), but the distribution of their abundance is spatially heterogeneous (Brown et al. 1995; Keitt et al. 2002).

The wild rabbit is one of the most appealing small game species for Spanish hunters (Vargas \& Muñoz 1996). Their populations in Spain have declined sharply during the second half of the last century due to the arrival of myxomatosis, in the mid 1950s, and the viral haemorrhagic disease in the late 1980s (Beltrán 1991). Both diseases caused a substantial reduction in wild rabbit population density and significant changes in their distribution (Muñoz 1960; Villafuerte et al. 1995; Calvete et al. 2002). According to Villafuerte et al. (1997), the current numbers of wild rabbits in the Iberian Peninsula are the lowest in decades. Concordantly to counts, hunting bag records also indicate a progressive decrease in the number of rabbits captured in Spain: For instance, the number of rabbits hunted in Spain decreased from more than 10 million in 1986 to four millions in 2000 (Statistics National Institute 2006).

*Correspondence: Juan Mario Vargas, Departamento de Biología Animal, Facultad de Ciencias, Universidad de Málaga, E-29071 Málaga, Spain. Tel: +34 9521318 61. Fax: +349521316 68. Email: jmvy@uma.es 
Andalusia (southern Spain) is one of the Spanish regions with the greatest game tradition, including nearly 9000 game estates that cover more than $90 \%$ of the territory (Guirado \& Ortega 2002), with about 250,000 hunting licences issued annually during the last 15 years (Junta de Andalucía 2003). According to official statistics, about 1.5 million rabbits are hunted in Andalusia per year (Junta de Andalucía 2004). This has resulted in the transformation of game, during the last decades, into a profitable activity (Lucio \& Purroy 1992), to the point that it may become an alternative economic activity in rural areas with marginal agriculture and stockbreeding uses (Fungesma 2001; Vargas 2002). The Andalusian territory is heterogeneous, which means that local hunting yields of rabbits vary widely among regions (Farfán et al. 2004). Because of this, it is necessary to explore the game potential of different parts of the territory to improve the regional planning of game activities. This would be useful to identify areas of interest for raptors and carnivores that prey on the rabbit, as rabbit abundance is important for many of them. Looking for new formulas to make game activities compatible with the conservation of the rabbit is also essential for several threatened predator species (Palma et al. 1999; Rodríguez \& Delibes 2003).

Farfán et al. (2004) studied the capture intensity of game mammals throughout Andalusia as a first step to optimise game management on a regional scale. They analysed mean annual hunting yields in each Andalusian municipality $(n=771)$ during the period $1993 / 2001$. The basic information was obtained from the mandatory Annual Hunting Reports (AHRs) that the game estates must submit to the regional government after each hunting season. They also modelled hunting yield favourableness for the wild rabbit in the Andalusian municipalities.

Our main objective was to identify areas favourable for obtaining good hunting yields of the wild rabbit in Andalusia, suitable for establishing future recovering areas for the species that could help to maintain or increase its population density. With this aim, we used the information available in the AHRs to downscale a model of the potential favourableness for rabbit harvesting in $1 \times 1 \mathrm{~km}$ squares in Andalusia, using environmental and land-use variables as predictors.

\section{Materials and methods}

Study area

Andalusia, one of the 17 Spanish autonomous regions, covers more than $87,000 \mathrm{~km}^{2}$ in the southernmost part of mainland Spain, and is administratively divided into eight provinces and 771 municipalities. The main mountain ranges are Sierra Morena, along the northern fringe of the region, and the Betic System, sub-divided into two ranges, Sub-betic and Penibetic, which are NE-SWoriented and occupy mainly the eastern part of the region. The most important plain is the Guadalquivir valley, which is longitudinally oriented between Sierra Morena and the Betic System (Figure 1). Its climate is Mediterranean, with mild winters and severe summer droughts. Mean annual temperature ranges from $9.8^{\circ} \mathrm{C}$ to $19.4^{\circ} \mathrm{C}$ (Font, 2000). Rainfall is highly heterogeneous, with a marked decreasing gradient of precipitation from west to east (minimum of $170 \mathrm{~mm}$ and maximum of $1800 \mathrm{~mm}$ of precipitation). Of the Andalusian land area, $47 \%$ is used for agriculture. Olive groves, which occupy $15 \%$ of the Andalusian territory, and cereals, cultivated in $11 \%$ of the territory, are the main crops, both of them fundamentally for dry farming. Thirty-eight per cent of the agricultural land is mountainous, and mountain crops are generally restricted to the inner valleys or to hillsides of little slope.

\section{Variables}

We analysed 32,134 AHRs from the period 1993/ 2001 reported by 6049 game estates distributed throughout the Andalusian municipalities, with information covering between four and nine hunting seasons for each municipality. As the digital maps of the game estates were not available, we ascribed each game estate to its corresponding municipality and estimated the average hunting yields of rabbit $(H Y)$ in each Andalusian municipality $(n=771)$, according to the following equation:

$$
H Y=\frac{\sum \begin{array}{l}
\text { mean annual number of } \\
\text { individuals hunted per game estate }
\end{array}}{\sum \text { areas of the game estates }} * 100,
$$

where $H Y$ is the hunting yield per municipality, in terms of the number of rabbits captured/100 ha of game estate.

As our aim was to detect areas favourable to obtaining high hunting yields, as opposed to predicting expected hunting yield values, we followed the criterion of Farfán et al. (2004) and Vargas et al. (2006) and considered a value of $H Y=20$ as the threshold between Andalusian municipalities with good yields and those with poor yields. Then we produced a new binomial variable, good hunting 

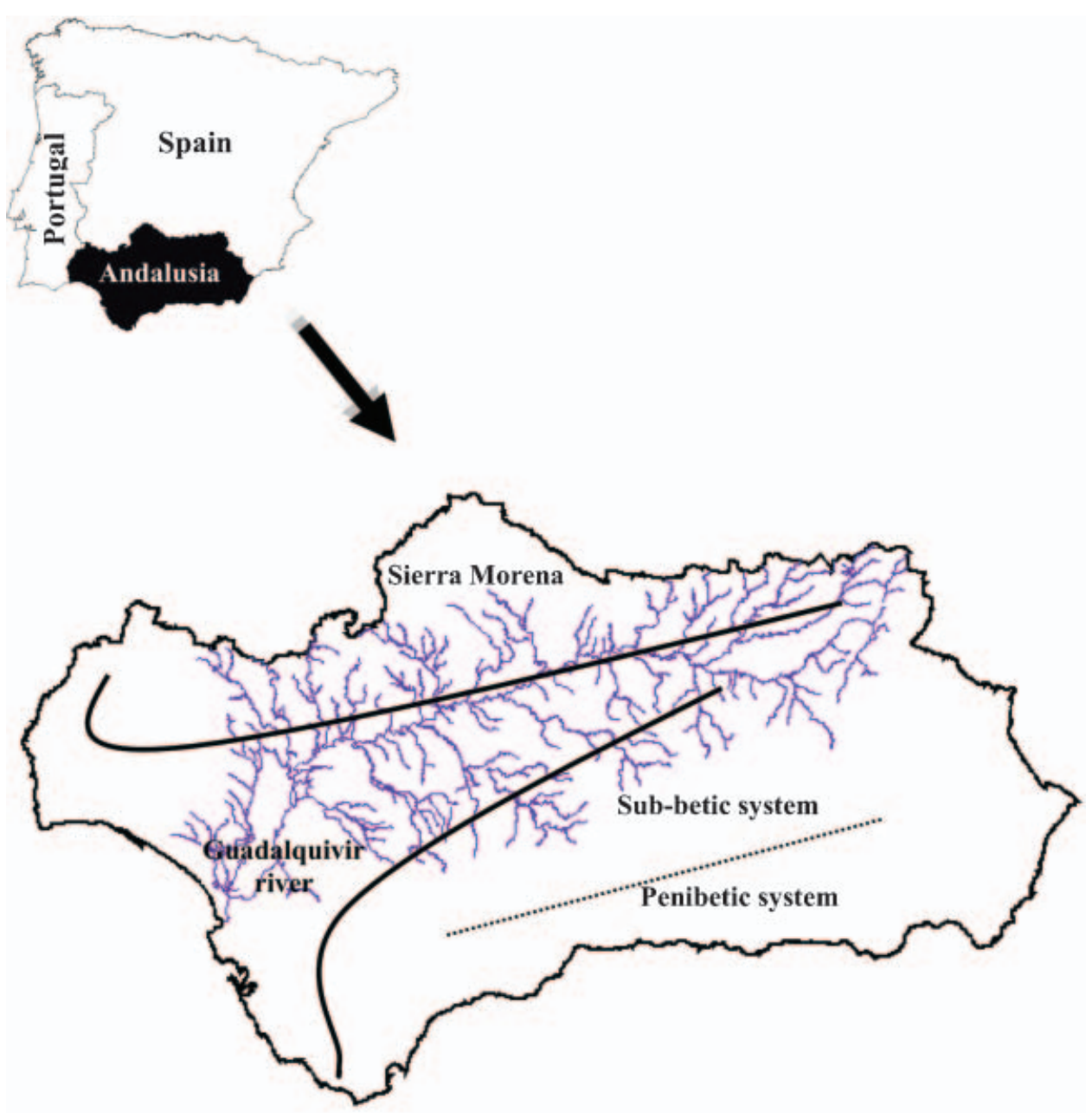

Figure 1. Study area. It is shown in schematic form the main mountain ranges (Sierra Morena and the Betic System, sub-divided into two ranges, Subbetic and Penibetic) and the most important river (Guadalquivir river).

yield $(G H Y)$, with a value of 1 in the municipalities with $H Y>20$ and 0 in those with $H Y \leqslant 20$, to be used as target variable in the modelling procedure.

We related $G H Y$ to 39 predictor variables that inform about the environmental characteristics, land use, and vegetation in the Andalusian municipalities (Table I). ALTI is released as a digital coverage by the Land Processes Distributed Active Archive Center, located at the US Geological Survey's EROS Data Center (http://LPDAAC.usgs.gov). SLOP was calculated from altitude using the Idrisi SLOPE command (Eastman 2004). Climatic variables data (from $H \mathcal{F A N}$ to PIRR) result from records of 30 years and are mostly considered to be representative of present climatic conditions (Font 2000) and were digitised using CartaLinx 1.2 and processed using Idrisi32 (see Barbosa et al. 2003 for a detailed explanation on the digitising methods). The variables related with land use and vegetation cover (IHER through $D S$ ) were obtained by transforming the corresponding digital polygons into raster images. All variables were rasterised with a spatial resolution of 1 pixel $=1 \mathrm{~km}^{2}$, which implies approximately 87,600 data for each variable. For land use variables, each pixel was assigned to the dominant land use. Finally, we extracted the mean value of the quantitative variables and the proportion of each type of land use and vegetation cover for each municipality.

We used these variables to assess the variation in hunting yields due to the overall action of environment and human activity. We did not include spatial variables because they can reveal a geographical trend in distribution that does not reflect the spatial structure of the environmental predictor variables (Borcard et al. 1992; Diniz-Filho et al. 2003; Kühn 2007), but to historical events or to migrations (Legendre 1993; Barbosa et al. 2001; Real et al. 2003), which are outside management scope. Models constructed with this kind of variables may 
Table I. Variables available to model the potential distribution of wild rabbit hunting yields in Andalusian municipalities.

\begin{tabular}{|c|c|}
\hline Code & Variables \\
\hline & Environmental variables \\
\hline$A L T I$ & Altitude $(\mathrm{m})^{(1)}$ \\
\hline SLOP & Slope (\%) \\
\hline$H \mathcal{F A N}$ & $\begin{array}{l}\text { Mean relative air humidity in January at } 07: 00 \text { hours } \\
(\%)^{(2)}\end{array}$ \\
\hline$H F U L$ & Mean relative air humidity in July at 07:00 hours $(\%)^{(2)}$ \\
\hline$H R A N$ & 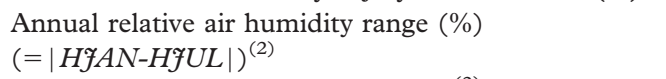 \\
\hline INSO & Mean annual insolation (hours/year) ${ }^{(2)}$ \\
\hline$T \mathscr{f A N}$ & Mean temperature in January $\left({ }^{\circ} \mathrm{C}\right)^{(2)}$ \\
\hline$T \mathscr{f U L}$ & Mean temperature in July $\left({ }^{\circ} \mathrm{C}\right)^{(2)}$ \\
\hline SRAD & Mean annual solar radiation $\left(\mathrm{kwh} / \mathrm{m}^{2} / \text { day }\right)^{(2)}$ \\
\hline ROFF & Mean annual run-off $(\mathrm{mm})^{(2)}$ \\
\hline TEMP & Mean annual temperature $\left({ }^{\circ} \mathrm{C}\right)^{(2)}$ \\
\hline TRAN & Annual temperature range $\left({ }^{\circ} \mathrm{C}\right)(=T \mathcal{F} U L-T f A N)^{(2)}$ \\
\hline DFRO & $\begin{array}{l}\text { Mean annual number of frost days (minimum } \\
\left.\text { temperature }<0^{\circ} \mathrm{C}\right)^{(2)}\end{array}$ \\
\hline PREC & Mean annual precipitation $(\mathrm{mm})^{(2)}$ \\
\hline PET & Mean annual potential evapotranspiration $(\mathrm{mm})^{(2)}$ \\
\hline PIRR & Pluviometric irregularity ${ }^{(3)}$ \\
\hline & Land use and vegetation variables \\
\hline IHER & Irrigated herbaceous crops $(\% \text { area })^{(4)}$ \\
\hline$I W C$ & Irrigated woody crops $(\% \text { area })^{(4)}$ \\
\hline DHER & Dry herbaceous crops (\% area) ${ }^{(4)}$ \\
\hline DHET & Dry heterogeneous crops (\% area) $)^{(4)}$ \\
\hline$B L$ & Built land $(\% \text { area })^{(4)}$ \\
\hline IHET & Irrigated heterogeneous crops $(\% \text { area })^{(4)}$ \\
\hline WETL & Wetlands $(\% \text { area })^{(4)}$ \\
\hline$D W C$ & Dry wood crops (\% area $)^{(4)}$ \\
\hline PAST & Pasture $(\% \text { area })^{(4)}$ \\
\hline$O A K W$ & Oak wood $(\% \text { area })^{(4)}$ \\
\hline$P W O$ & Pasture with oaks (\% area) $)^{(4)}$ \\
\hline$P W C$ & Pasture with conifers $(\% \text { area })^{(4)}$ \\
\hline$D S W O$ & Dense scrub with oaks (\% area) ${ }^{(4)}$ \\
\hline$S S$ & Sparse scrub $(\% \text { area })^{(4)}$ \\
\hline$M C N V$ & Mosaic of crops and natural vegetation (\% area) $)^{(4)}$ \\
\hline SSWO & Sparse scrub with oaks $(\% \text { area })^{(4)}$ \\
\hline$H C W O$ & Herbaceous crops with oaks (\% area) ${ }^{(4)}$ \\
\hline$D S W C$ & Dense scrub with conifers $(\% \text { area })^{(4)}$ \\
\hline$S S W C$ & Sparse scrub with conifers $(\% \text { area })^{(4)}$ \\
\hline$S S W D$ & Sparse scrub with diverse trees $(\% \text { area })^{(4)}$ \\
\hline$D S W D$ & Dense scrub with diverse trees (\% area) $)^{(4)}$ \\
\hline$C W$ & Conifer wood $(\% \text { area })^{(4)}$ \\
\hline$D S$ & Dense scrub $(\% \text { area })^{(4)}$ \\
\hline
\end{tabular}

Sources: (1) US Geological Survey (1996); (2) Font (1983); (3) Montero de Burgos y González-Rebollar (1974); (4) Mapa de usos y coberturas vegetales del suelo de Andalucía (Consejería de Medio Ambiente 1999)

have the same validity as those where the spatial autocorrelation is considered (Diniz-Filho et al. 2003).

\section{Predictive models}

To select a subset of significant predictor variables we performed stepwise logistic regression (Hosmer
\& Lemeshow 1989) of $G H Y$ on each variable separately, using the SPSS 10.0 statistical software. We dealt with the familywise error rate (i.e. the increase of type I error under repeated testing) by controlling the false discovery rate $(F D R)$ (Benjamini \& Hochberg 1995; García 2003) using the procedure for all forms of dependency among test statistics proposed by Benjamini and Yekutieli (2001). We used the variables that were significant under a FDR of $q<0.05$ to build a stepwise multiple logistic regression model of the distribution of good hunting yields, and the step with the best Akaike's information criterion (AIC) score was selected (Akaike 1973). Then we used the environmental favourability function described by Real et al. (2006) to eliminate from the model the effect of the uneven proportion of ones and zeros in the data set. The favourableness for a good hunting yield in each municipality is obtained from the formula:

$$
F=(P /(1-P)) /\left(\left(n_{1} / n_{0}\right)+(P /(1-P))\right)
$$

where $P$ is the probability value given by logistic regression, and $n_{1}$ and $n_{0}$ are the number of municipalities with good and poor hunting yields, respectively (Real et al. 2006). This function provides a description of local deviations from the overall probability of obtaining good hunting yields. This implies that, for example, a value $F>0.5$ means that the probability of obtaining good hunting yields, expected according to local environmental conditions, is higher than that expected according to the prevalence of reported good hunting yields in the territory.

To obtain an explanatory model, the variables introduced in the final predictive model were grouped in orographical, climatic and vegetation factors (Table I), and we used each group of variables to obtain partial orographic, climatic, and vegetation favourableness models. To take into account interactions between these factors, which often result in an overlaid effect in space due to colinearity between them (Borcard et al. 1992; Legendre 1993), we performed a variation partitioning procedure to specify how much of the variation of the final model $\left(R_{i+j+\ldots+n}^{2}\right)$ was explained by the pure effect of each explanatory factor, and which proportion was attributable to their interrelationships (Legendre 1993; Legendre \& Legendre 1998). The part of the variation of the final model explained by each factor $\left(R_{i}^{2}\right)$ was obtained by regressing the values obtained in the final model on those yielded by each partial favourableness model. The amount of variation explained by each pair, trio, etc. of factors $\left(R_{i+j+\ldots+n}^{2}\right)$ may be obtained by regressing 
the final model values on those yielded by the favourableness models using these factors together. Then, the pure effect of each factor $\left(R_{p i}^{2}\right)$ may be assessed by subtracting the variation explained by the others factors together from the variation explained by the final model $\left(R_{p i}^{2}=R_{i+j+\ldots+n}^{2}-R_{j+\ldots+n}^{2}\right)$. The variation attributable to the exclusive interrelationship of pairs of factors $\left(R_{i j}^{2}\right)$ may be obtained by subtracting from $R_{i+j+\ldots+n}^{2}$ the pure effect of the two factors $\left(R_{p i}^{2}+R_{p j}^{2}\right)$ and the variation explained by the other factors together $\left(R_{k+\ldots+n}^{2}\right)$. The variation attributable to interrelationships among trios, quartets, etc., may be obtained analogously by subtraction (see Whittaker 1984; Legendre \& Legendre 1998).

The favourability equation was used to create a downscaled image representing the favourableness of obtaining good hunting yields for the wild rabbit in $1 \times 1 \mathrm{~km}$ squares in Andalusia, using the Idrisi Image Calculator. Analogously, we also downscaled the partial climatic, orographic, and vegetation models. Consequently, all the inferences were made at the municipality level, with 771 independent samples, and the models at $1 \times 1 \mathrm{~km}$ resolution are deductive model derived from the former, inductive model. The response variable in the municipal model is referred to as hunting yield per $100 \mathrm{ha}$, so that we assumed it is transferable to $1 \times 1 \mathrm{~km}$ squares (since $100 \mathrm{ha}=1 \mathrm{~km}^{2}$ ).

Finally, we obtained quality categories for the territory by combining the probability values given by logistic regression with those of the environmental favourableness function (Table II). For both probability and favourableness we established three categories, good for values higher than 0.75 , intermediate for values between 0.25 and 0.75 , and bad for values lower than 0.25 . The combination of these ranges produces five quality categories for the territory according to their favourableness for obtaining good hunting yields and the probability of actually obtaining them. If an area has a good probability and a good favourableness for obtaining good hunting yields, then it is considered as "very good", if both probability and favourableness are

Table II. Quality categories established to classify the areas according to the probability and the favourableness for obtaining good hunting yields.

\begin{tabular}{lcc}
\hline Categories & Probability range & Favourableness range \\
\hline Very good & $>0.75$ & $>0.75$ \\
Good & $0.25-0.75$ & $>0.75$ \\
Intermediate & $0.25-0.75$ & $0.25-0.75$ \\
Bad & $<0.25$ & $0.25-0.75$ \\
Very bad & $<0.25$ & $<0.25$ \\
\hline
\end{tabular}

intermediate then the area is also "intermediate", and if both are bad then the area is "very bad". When either the probability or the favourableness is good and the other is intermediate then the area is considered as "good", and when one of them is bad and the other is intermediate the area is "bad". We applied these quality categories to the $1 \times 1 \mathrm{~km}$ squares of Andalusia, and represented them in a map to show the exact location of good and bad areas within the municipalities.

\section{Results}

The logit function of the logistic regression model, with the variables ranked according to their order of entrance in the model and variables abbreviations as in Table I, is the following:

$$
\begin{aligned}
y= & 12.40-A L T I \times 0.0028+D W C \times 2.91-T E M P \\
& \times 0.88+P A S T \times 7.71+T F A N \times 0.34-S L O P \\
& \times 0.13-D F R O \times 0.031
\end{aligned}
$$

The municipalities favourable for obtaining good hunting yields of wild rabbits in Andalusia, according to these variables, tend to be aggregated (Figure 2).

The relationship among explanatory factors was complex (Figure 3). The effect due to the interrelationship between vegetation and orography was positive, as well as the effect due to the interrelationship among vegetation, orography and climate together. This means that the characteristics of these factors that favour good hunting yields tend to be present simultaneously. However, the effect due to the interrelationship between climate and orography after excluding the effect of vegetation was negative, as was also the case of the effect due to the interrelationship between climate and vegetation after excluding the effect of orography. From a mathematical point of view, these negative values measure the amount in which the effect of a factor is obscured by another factor through interrelationships between variables (Cartron et al. 2000; Bárcena et al. 2004). This means that the favourable climatic conditions tend not to coincide with the favourable orographic conditions given constant vegetation, or with the favourable vegetational conditions given a constant orography.

The most favourable areas for wild rabbit hunting yields are mainly located along the Guadalquivir slope of the Subbetic Range. However, the $1 \times 1 \mathrm{~km}$ squares with favourableness values higher than 0.8 are scattered throughout the territory (Figure 4 ). 


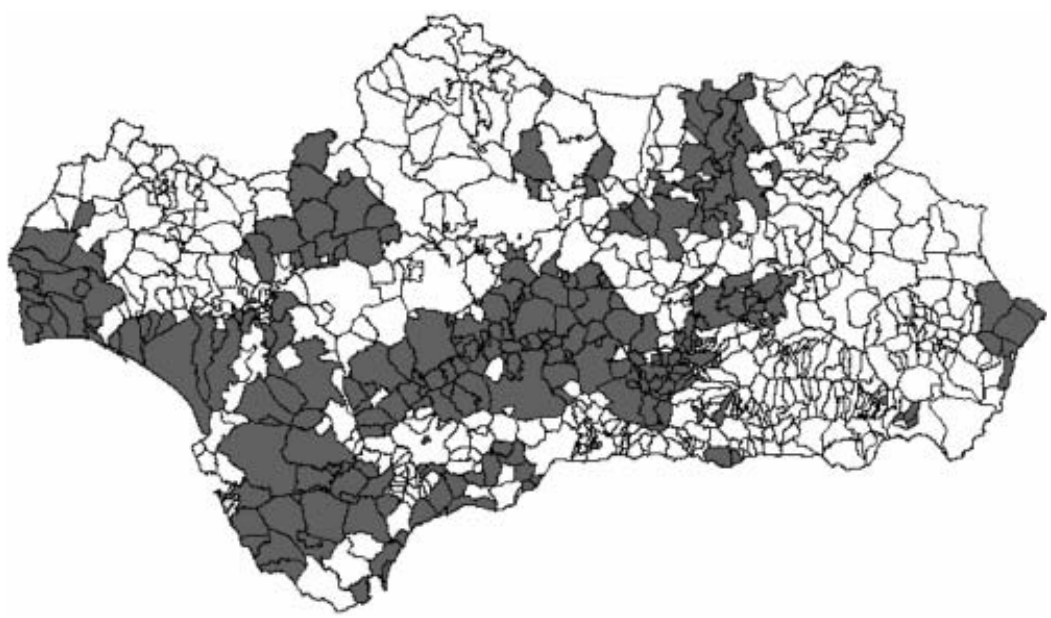

Figure 2. Municipalities holding good hunting yields (GHY) in Andalusia (in dark).

The models obtained for the orographical, climatic, and vegetation factors separately suggest that the scattered nature of good hunting yields seems to be caused mainly by the effect of vegetation (Figure 5).

Figure 6 shows the quality category of each $1 \times 1 \mathrm{~km}$ square of Andalusia according to the categories established in Table II.

\section{Discussion}

\section{Relation between hunting yield and rabbit abundance}

Although density and hunting yield are not always equivalent parameters (Lucio 1991), hunting yields obtained from AHRs have been shown to provide a sufficiently realistic image, at a macrospatial scale, of good and poor areas for a species (Farfán et al. 2004; Vargas et al. 2006, 2007). Therefore, the use of reported hunting yields is an easy and cheap method for assessing relative abundances of wild rabbits at a regional scale, when relative abundance values per

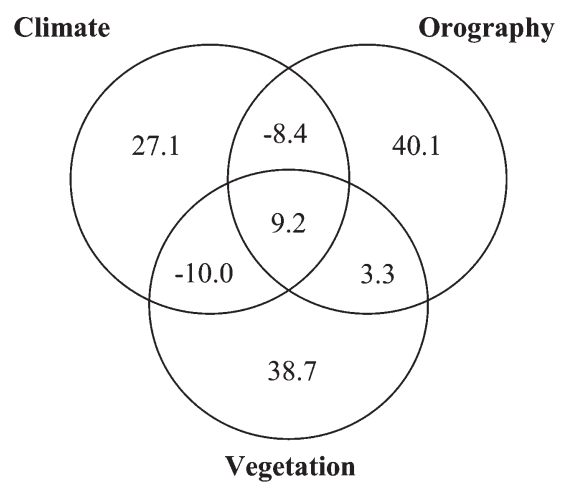

Figure 3. Variation partitioning of the final model. Values shown in the diagrams are the percentages of variation in good hunting yield explained by the indicated factors and by their interactions. unit area are scarce. However, hunting yields are affected by human-induced land use, and not only reflect favourable environmental conditions for the rabbit, which is why we included land-use variables in our models.

Hunting yields are also affected by rabbit restocking, which is carried out with increasing frequency and partially masks the actual local scarcity of native individuals. If, for example, restocking activities were concentrated in few areas of low density, they could mask the actual population level and productivity and the results of the analyses would be correspondingly biased. However, this effect, although certainly existing, is likely to be small, as official reports indicate that rabbit farms in Andalusia produce about 15,000 wild individuals for restocking purposes per year (Vargas 2002), which represent only $2 \%$ of the total number of rabbits hunted. Many of the animals released were translocated from high-density game estates of Andalusia and Extremadura, but the mortality among these individuals is very high (Letty et al. 2002; Calvete \& Estrada 2004), so their effect on the values of hunting yield is not likely to be high.

\section{The scattered distribution of good hunting yields}

The municipalities with good hunting yields are clumped in several homogeneous groups located mainly in the Guadalquivir valley, along the axis of the Subbetic Range, and in certain areas of Sierra Morena. However, our downscaled favourableness model (Figure 5) predicts a patchy distribution of the areas with high favourableness for good hunting yields of rabbit, which suggests that only some areas within each municipality are highly favourable for obtaining good hunting yields for this species. In 

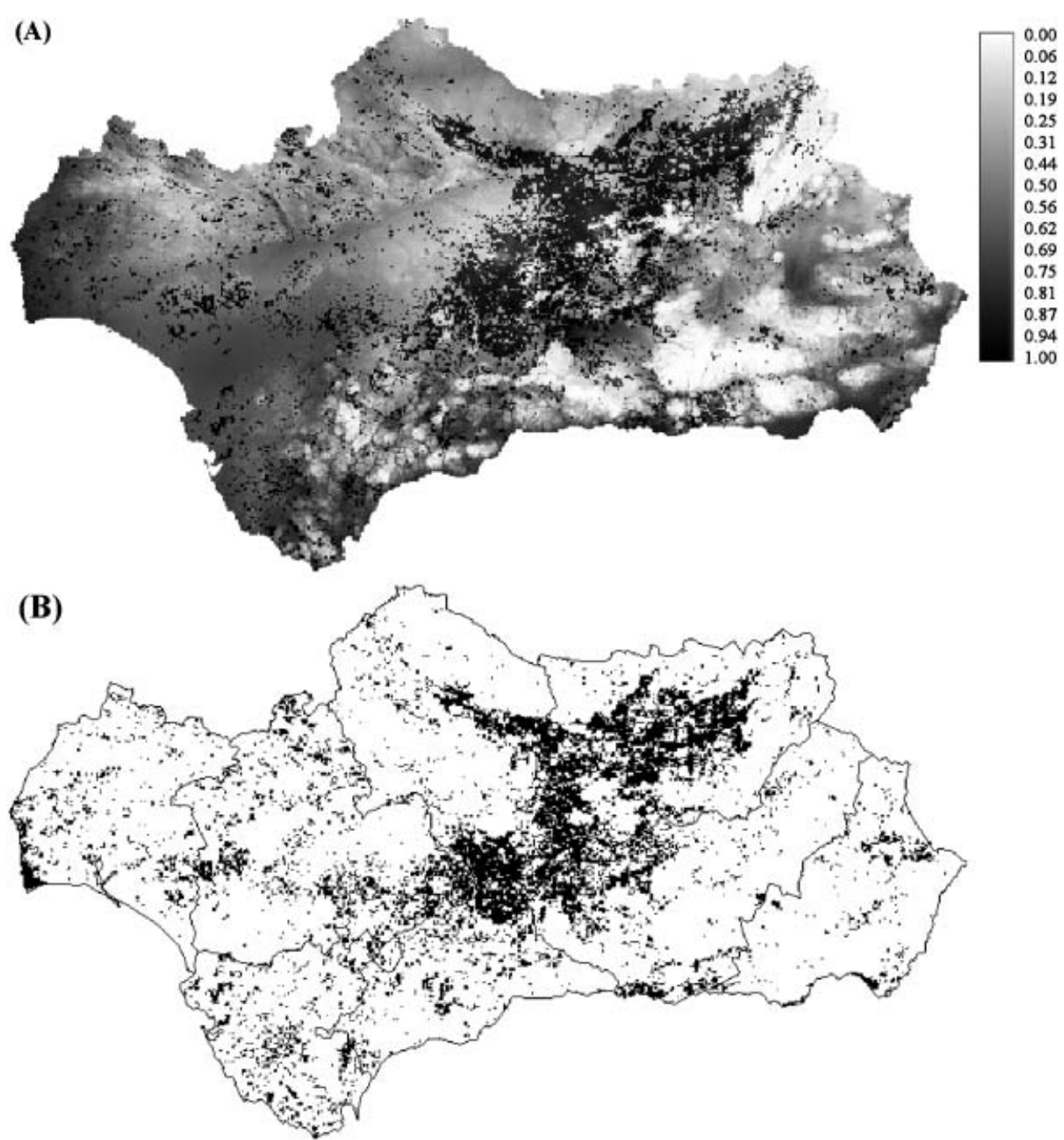

Figure 4. A, Favourableness values for wild rabbit good hunting yields in each $1 \times 1 \mathrm{~km}$ square of Andalusia, shown on a scale ranging from 0 (white) to 1 (black). B, Only the $1 \times 1 \mathrm{~km}$ squares where the favourableness to obtain good hunting yields is higher than 0.8 are shown (in black). Black lines correspond to province limits.

fact, very good squares are scattered throughout the territory (Figure 6). This may reflect a current spatial trend of wild-rabbit demography, as Villafuerte et al. (1995) found that, all over Spain, the rabbit haemorrhagic disease has particularly affected suboptimum territories leaving populations with high rabbit density restricted to disperse patches of high quality habitat.

Other causes not reflected in our models, such as the widespread fragmentation of agricultural landscapes, may have contributed to this spatial pattern by causing many rabbit populations to become fragmented, and consequently, more vulnerable to demographic and environmental risks (Trout et al. 1992; Marchandeau et al. 1998; Letty et al. 2002). In the Iberian Peninsula, human-induced habitat changes and excessive hunting pressure have also been reported to make a dent in local rabbit abundance (Diamond et al. 1987; Beltrán 1991).

The partial climatic, orographic, and vegetation models

According to our model, the areas most favourable for obtaining good hunting yields for the wild rabbit in Andalusia occur in low altitude plains with mild summers and warm winters and a combination of dry wood crops and pasture. These results are in accordance with the type of environment where the highest densities of the species are detected in nature. Villafuerte (2002) and Calvete et al. (2004), for example, reported the wild rabbit to be linked mainly to cultivated areas with low slope and 

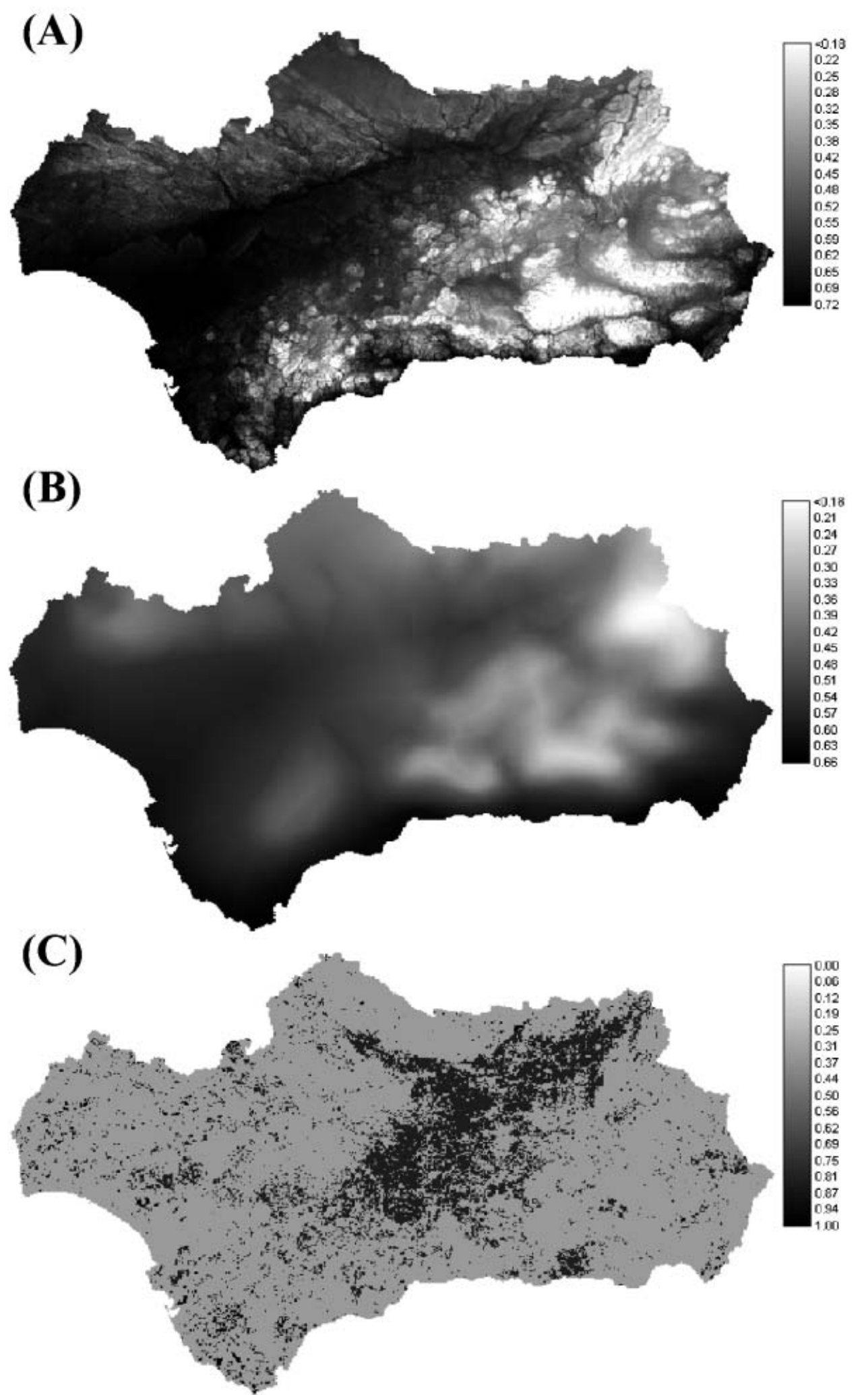

Figure 5. Favourableness maps predicted by the orographical (A), climatic $(\mathbf{B})$ and vegetation $(\mathbf{C})$ factors in each $1 \times 1 \mathrm{~km}$ square of Andalusia. 


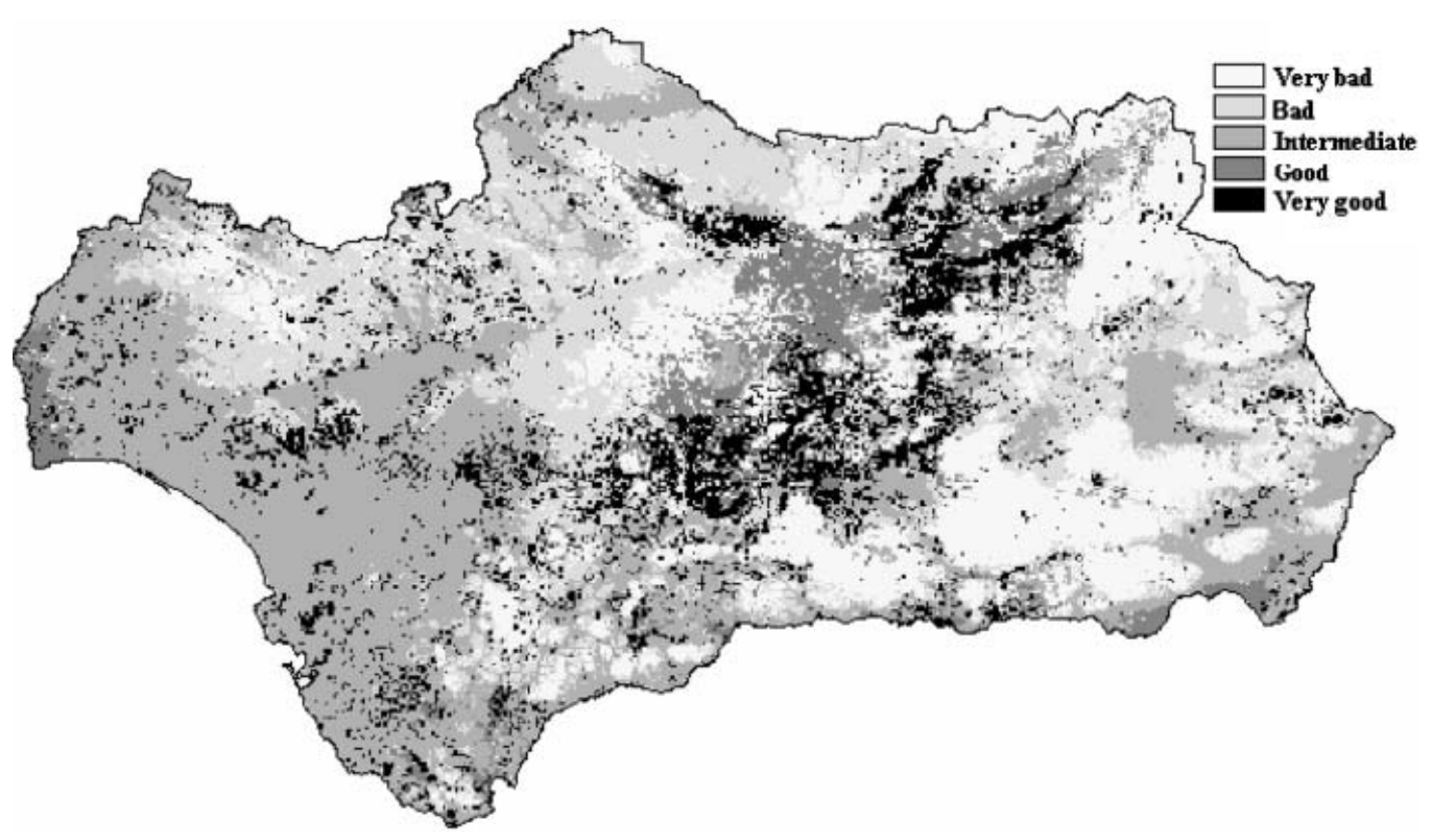

Figure 6. Quality category of each $1 \times 1 \mathrm{~km}$ square of Andalusia according to the categories established in Table II.

arid weather characterised by warm winters, and altitude is considered a limiting factor for this species (Ballesteros 1998, but see Flux 2001).

Orography is the most important factor explaining the distribution of good hunting yields in Andalusia. However, this factor, which may affect both the rabbit and the hunters, as steep terrain is generally avoided by hunters, is difficult to manage.

Figure 5 suggests that vegetation, an easier factor to manage, is responsible for the patchy distribution of good hunting yields. The high pure effect of vegetation on the final model (see Figure 3) should be taken into account in the management of this species. Calvete et al. (2004), for instance, pointed out that rabbits in Mediterranean areas feed mainly on crops, and Boag (1987) found that vegetation cover and land use are determinant in the presence and abundance of rabbits.

The negative interrelation of pure climate with pure vegetation and pure orography indicates that given the same orographical condition the effects of climate and vegetation on good hunting yields oppose one another, and in the same vegetational structure the effects of climate and orography are discordant. That is to say, in plain areas dry wood crops and pasture (favourable for the rabbit) tend to be located in terrains that support harsh summers and winters (unfavourable for the species), and in areas with dry wood crops and pasture mild summers and winters occur in elevated and steep terrain (unfavourable for the rabbit).

\section{Implications in management and conservation}

An important consequence of the decline in rabbit numbers has been an increase in extensive and usually illegal persecution of predators (Villafuerte et al. 1998), a tendency that will probably be difficult to reverse as long as the density of rabbits, and the corresponding hunting success, remain low (de Juana 1989; Reynols \& Tapper 1996).

Sierra Morena, the mountain chain that crosses Andalusian northern region, supports the two most endangered Iberian predators, the Iberian imperial eagle (Aquila adalberti) and the Iberian lynx (Lynx pardinus), both of which prey on rabbits. Traditional land uses favourable for the rabbit have been abolished in many protected areas (Machado 1988) and rabbits, which were previously abundant (Servicio de Pesca Continental, Caza y Parques Nacionales 1968), have declined. In fact, according to our model, many of these areas have ceased to be favourable for rabbit hunting. Long-term conservation plans for the above-mentioned predators should not be based on the periodical release of rabbits in their territories, since the population density of this species in particular, and game species in general, depends fundamentally on the characteristics of their habitats (Tapper \& Barnes 1986; Palomares et al. 1996; Panek \& Kamieniarz 1999; Herranz et al. 2000).

The scarcity of rabbits entails an economic problem in areas where it is valuable as traditional game species (Moreno \& Villafuerte 1995). This 
may be exacerbated by excessive hunting pressure, a fact that hunters themselves acknowledge (Vargas \& Muñoz 1996). About $75 \%$ of Andalusian game estates implemented self-imposed hunting restrictions to improve rabbit populations (Vargas et al. 2004), particularly in areas of high rabbit abundance (Angulo \& Villafuerte 2003).

On the other hand, the current dates of the hunting season have a negative impact on rabbit abundance (Smith \& Trout 1994). The current hunting season for the rabbit in Andalusia involves two periods: from mid July to mid September, after the rabbit breeding season, and from mid October to the end of November, at the beginning of the reproductive activity. The first period was historically aimed at avoiding crop damage (REGHAB 2002), because the wild rabbit has traditionally been considered a pest species for agriculture, due to the damage it caused to local herbaceous crops and to young plantations of woody crops (Duarte et al. 2002; Angulo \& Villafuerte 2003). However, in the current low-density situation, only in some places it is necessary to control its populations (Drollette 1996; Hone 1999; Angulo 2001). The second period has been traditionally considered the main rabbit hunting period. Hunting in summer optimises hunting harvest while conserving rabbit populations (Gonçalves et al. 2002), but in October-November it has a detrimental effect on rabbit populations and hunting bags, as it precedes reproduction (Angulo \& Villafuerte 2003). Because of this, almost half the hunters in Andalusia disagree with the current hunting season (Vargas \& Muñoz 1996; Angulo \& Villafuerte 2003). However, Lande et al. (1997) showed that the detrimental effect of hunting on rabbit conservation is higher in areas with low abundance, as population stability is reduced. In these poor-quality populations, the hunting season has a weaker effect than hunting pressure on the population growth rate (Angulo \& Villafuerte 2003). In spite of this, neither hunters nor the Andalusian Government usually apply hunting restrictions in areas of low rabbit density.

We agree with the recommendation of Angulo \& Villafuerte (2003) that management agencies in Andalusia should review the rabbit hunting policy, adapt it to the current situation, and implement measures in accordance with hunters to conserve rabbit populations in areas of low rabbit abundance. The favourableness model (Figure 5) and the combined image of favourableness and probability (Figure 6) are useful tools that should be considered in future management plans of this species to reach this objective. For a rare species it is difficult to obtain good hunting yields even in favourable areas, whereas for common species the probability of obtaining good hunting yields is high in areas with intermediate favourableness. We believe that, to reach a more realistic regulation of game pressure, it is necessary to apply a differential management policy in areas with optimal and suboptimal densities, on the basis of the characteristics of the different regions. To reverse the regressive trend of the wild rabbit it is necessary to apply game management at a regional scale, confronting the problems under a macro-spatial perspective and carrying out joint actions comprising large and environmentally homogeneous territories. Technical Hunting Plans and Annual Hunting Reports are useful information sources for researchers, officials, and game managers who work to obtain more effective and sustainable game management models.

\section{Acknowledgements}

This work was financed by the Consejería de Innovación, Ciencia y Empresa de la Junta de Andalucía (Research Project P05-RNM-00935). A.M.B. was supported by a doctoral grant from Fundacão para a Ciêcia e a Tecnologia, Portugal. We also thank the Consejería de Medio Ambiente de la Junta de Andalucía for supplying the Annual Hunting Reports, and Rafael Villafuerte for his suggestions to a previous version of the manuscript.

\section{References}

Akaike H. 1973. Information theory and an extension of the maximum likelihood principle. In: Petrov BN, Csaki F, editors. Proceedings of the Second International Symposium on Information Theory. Budapest: Akademiai Kiado. pp 267-281.

Angulo E. 2001. When DNA research menaces diversity. Nature 410:739.

Angulo E, Villafuerte R. 2003. Modelling hunting strategies for the conservation of wild rabbit populations. Biological Conservation 115:291-301.

Ballesteros F. 1998. Las especies de caza en España. Biología, ecología y conservación. Estudio y Gestión del Medio. Oviedo: Estudio y Gestión del Medio, D.L.

Barbosa AM, Real R, Márquez AL, Rendón MA. 2001. Spatial, environmental and human influences on the distribution of otter (Lutra lutra) in the Spanish provinces. Diversity and Distributions 7:137-144.

Barbosa AM, Real R, Olivero J, Vargas JM. 2003. Otter (Lutra lutra) distribution modeling at two resolution scales suited to conservation planning in the Iberian Peninsula. Biological Conservation 114:377-387.

Bárcena S, Real R, Olivero J, Vargas JM. 2004. Latitudinal trends in breeding waterbird species richness in Europe and their environmental correlates. Biodiversity and Conservation 13:1997-2014. 
Beltrán JF. 1991. Temporal abundance pattern of the wild rabbit in Doñana, SW Spain. Mammalia 55:591-599.

Benjamini Y, Hochberg Y. 1995. Controlling the false discovery rate: A practical and powerful approach to multiple testing. Journal of the Royal Statistical Society 57:289-300.

Benjamini Y, Yekutieli D. 2001. The control of the false discovery rate in multiple testing under dependency. The Annals of Statistics 29:1165-1188.

Boag B. 1987. Reduction in numbers of the wild rabbit (Oryctolagus cuniculus) due to changes in agricultural practices and land use. Crop Protection 6:347-351.

Borcard D, Legendre P, Drapeau P. 1992. Partialling out the spatial component of ecological variation. Ecology 73:1045-1055.

Brown JH, Mehlman DW, Stevens GC. 1995. Spatial variation in abundance. Ecology 76:2028-2043.

Calvete C, Estrada R. 2004. Short-term survival and dispersal of translocated European wild rabbits. Improving the release protocol. Biological Conservation 120:507-516.

Calvete C, Estrada R, Angulo E, Cabezas-Ruiz S. 2004. Habitat factor related to wild rabbit conservation in an agricultural landscape. Landscape Ecology 19:531-542.

Calvete C, Estrada R, Villafuerte R, Osácar JJ, Lucientes J. 2002. Epidemiology of viral haemorrhagic disease (VHD) and myxomatosis in a free-living populations of wild rabbits. The Veterinary Record 150:776-782.

Cartron J-L E, Kelly JF, Brown JH. 2000. Constraints on patterns of covariation: A case study in strigid owls. Oikos 90:381-389.

Consejería de Medio Ambiente. 1999. Mapa de usos y coberturas vegetales del suelo de Andalucía. Sevilla: Junta de Andalucía.

Delibes M, Hiraldo F. 1981. The rabbit as prey in the Iberian Mediterranean Ecosystem. In: Myers K, MacInnes CD, editors. Proceedings of the I World Lagomorph Conference Guelph. University of Guelph, Canada. pp 614-622.

Delibes M, Rodríguez A, Ferreras P. 2000. Action Plan for the Conservation of the Iberian Lynx (Lynx pardinus) in Europe, n. 111. Strasbourg: Council of Europe Publishing.

Diamond AW, Schreiber RL, Attenborough D, Prestt I. 1987. Save the birds. Cambridge: Cambridge University Press.

Diniz-Filho JA, Bini LM, Hawkins BA. 2003. Spatial autocorrelation and red herrings in geographical ecology. Global Ecology and Biogeography 12:53-64.

Drollette D. 1996. Australia fends off critic of plan to eradicate rabbits. Science 272:191-192.

Duarte J, Vargas JM, Farfán MA. 2002. Biología de la liebre ibérica (Lepus granatensis). Bases técnicas para la gestión cinegética. In: Lucio A, Sáenz de Buruaga $M$, editors. Aportaciones a la gestión sostenible de la caza en España. Madrid: Ex Libris. pp 23-53.

Eastman JR. 2004. Idrisi Kilimanjaro GIS, User Guide and Software. Clark Labs, Clark University, Worcester, USA.

Farfán MA, Guerrero JC, Real R, Barbosa AM, Vargas JM. 2004. Caracterización del aprovechamiento cinegético de los mamíferos en Andalucía. Galemys 16:41-59.

Ferrer M. 2001. The Spanish Imperial Eagle. Barcelona: Lynx Edicions.

Flux JEC. 1994. World distribution. In: Thompson HV, King CM, editors. The European rabbit. The history and biology of a successful colonizer. Oxford: Oxford University Press. pp 8-21.

Flux JEC. 2001. Rabbits (Oryctolagus cuniculus) on Ruapehu at $1800 \mathrm{~m}$. New Zealand Journal of Zoology 28:429-430.

Font I. 1983. Atlas climático de España. Madrid: Instituto Nacional de Meteorología.
Font I. 2000. Climatología de España y Portugal. Salamanca: Ediciones Universidad de Salamanca.

Franco AMA, Brito JC, Almeida J. 2000. Modelling habitat selection of common cranes Grus grus wintering in Portugal using multiple logistic regression. Ibis 142:351-358.

Fungesma. 2001. Buenas Prácticas Cinegéticas. Madrid: Mundiprensa.

García LV. 2003. Controlling the false discovery rate in ecological research. Trends in Ecology and Evolution 18:553-554.

Gonçalves H, Alves PC, Rocha A. 2002. Seasonal variation in the reproductive activity of the wild rabbit (Oryctolagus cuniculus algirus) in a Mediterranean ecosystem. Wildlife Research 29:165-173.

Guirado J, Ortega F. 2002. La caza como actividad de desarrollo sostenible. Medio Ambiente 41 (monográficos 16):22-26.

Herranz J, Yanes M, Suárez F. 2000. Relaciones entre la abundancia de las especies de caza menor, sus depredadores y la estructura del hábitat en Castilla-La Mancha (España). Ecología 14:219-233.

Homolka M, Zima J. 1999. Oryctolagus cuniculus (Linnaeus, 1758). In: Mitchell-Jones AJ, Amori G, Bogdanowicz W, Krystufek B, Reijnders PJH, Spitzenberger F, Stubbe M, Thissen JBM, Vohralík V, Zima J, editors. The atlas of European mammals. London: $\mathrm{T} \& \mathrm{AD}$ Poyser Ltd. pp 172-173.

Hone J. 1999. On rate of increase (r): Patterns of variation in Australian mammals and the implications for wildlife management. Journal of Applied Ecology 36:709-718.

Hosmer DW, Lemeshow S. 1989. Applied logistic regression. New York: John Wiley \& Sons, Inc.

Juana E. 1989. Situación actual de las rapaces diurnas (O. Falconiformes) en España. Ecologia 3:237-292.

Junta de Andalucía. 2003. Informe Medioambiental 2001. http:// www.juntadeandalucia.es. Accessed 2006 Oct 10.

Junta de Andalucía. 2004 http://www.juntadeandalucia.es/ medioambiente/cazaypesca. Accessed 2006 Oct 10.

Keitt HK, Bjørnstand ON, Dixon PM, Citron-Pousty S. 2002. Accounting for spatial pattern when modeling organismenvironment interactions. Ecography 25:616-625.

Kühn I. 2007. Incorporating spatial autocorrelation may invert observed patterns. Diversity and Distributions 13:66-69.

Lande R, Saether BE, Engen S. 1997. Threshold harvesting for sustainability of fluctuating resources. Ecology 78:1341-1350.

Legendre P. 1993. Spatial autocorrelation: Trouble or new paradigm? Ecology 74:1659-1673.

Legendre P, Legendre L. 1998. Numerical ecology. 2nd English ed. Amsterdam: Elsevier Science.

Letty J, Marchandeau S, Reitz F, Clobert J, Sarrazin F. 2002. Survival and movements of translocated Wild rabbits (Oryctolagus cuniculus). Game Wildlife Science 19:1-23.

Lucio A. 1991. Ordenación y gestión en caza manor. In: Fuentes A, Sánchez I, Pajuelo L., editors. Manual de ordenación y gestión cinegética. Badajoz: IFEBA. pp 219-255.

Lucio A, Purroy FJ. 1992. Caza y conservación de aves en España. Ardeola 39:85-98.

Machado A. 1988. El Parque Nacional, una figura de protección. In: Machado A, editor. Los Parques Nacionales. Aspectos Jurídicos y Administrativos. Madrid: ICONA. pp 13-24.

Marchandeau S, Chantal J, Portejoie Y, Barraud S, Chaval Y. 1998. Impact of viral hemorrhagic disease on wild population of European rabbits in France. Journal of Wildlife Disease 34:429-435

Monnerot M, Vigne JD, Biju-Duval C, Casane D, Callou D, Hardy C, Mougel F, Soriguer RC, Dennebouy RC, 
Mounolou N. 1994. Rabbit and man: Genetic and historic approach. Genetic Selection Evolution 26:167-182.

Montero de Burgos JL, González-Rebollar JL. 1974. Diagramas bioclimáticos. Madrid: ICONA. pp 45-48.

Moreno S, Villafuerte R. 1995. Traditional management of scrubland for the conservation of rabbits (Oryctolagus cuniculus) and their predators in Doñana National Park, Spain. Biological Conservation 73:81-85.

Muñoz G. 1960. Anverso y reverso de la mixomatosis. Madrid: Dirección General de Montes, Caza y Pesca Fluvial.

Palma L, Beja P, Rodríguez M. 1999. The use of sighting data to analyse Iberian lynx habitat and distribution. Journal of Applied Ecology 36:812-824.

Palomares F, Calzada J, Revilla E. 1996. El manejo de hábitat y la abundancia de conejos: Diferencias entre dos áreas potencialmente idénticas. Revista Florestal 9:201-210.

Panek M, Kamieniarz R. 1999. Relationships between density of brown hare Lepus europaeus and landscape structure in Poland in the years 1981-1995. Acta Theriologica 44:67-75.

Real R, Barbosa AM, Porras D, Kin MS, Márquez AL, Guerrero JC, Palomo LJ, Justo ER, Vargas JM. 2003. Relative importance of environment, human activity and spatial situation in determining the distribution of terrestrial mammal diversity in Argentina. Journal of Biogeography 30:939-947.

Real R, Barbosa AM, Vargas JM. 2006. Obtaining environmental favourability functions from logistic regression. Environmental and Ecological Statistics 13:237-245.

REGHAB. 2002. Reconciling gamebird hunting and biodiversity. V Forework Program of the European Union. Proposal number Ekv-2000-00637, Geneva.

Reynolds JC, Tapper SC. 1996. Control of mammalian predators in game management and conservation. Mammal Review 26:127-156.

Rodríguez A, Delibes M. 2003. Population fragmentation and extinction in the Iberian lynx. Biological Conservation 109:321-331.

Servicio de Pesca Continental, Caza y Parques Nacionales. 1968. Mapa Cinegético Nacional. Avance informativo. Conejo (Oryctolagus cuniculus). Madrid: Ministerio de Agricultura.

Smith GC, Trout RC. 1994. Using Leslie matrices to determine wild rabbit population growth and the potential for control. Journal of Applied Ecology 31:223-230.

Statistics National Institute. 2006. http://www.ine.es. Accessed 2006 Oct 10 (In Spanish).

Tapper SC, Barnes FW. 1986. Influence of farming practice on the ecology of the brown hare (Lepus europaeus). Journal of Applied Ecology 23:39-52.

Teixeira J, Ferrand N, Arntzen JW. 2001. Biogeography of the golden-striped salamander, Chioglossa lusitanica: A field survey and spatial modelling approach. Ecography 24:618-623.

Trout RC, Ross J, Tittensor AM, Fox AP. 1992. The effect on a British wild rabbit population (Oryctolagus cuniculus) of manipulating myxomatosis. Journal of Applied Ecology 29: 679-686.

US Geological Survey. 1996. GTOPO30. Land Processes Distributed ArchiveCenter, http://edcdaac.usgs.gov/gtopo30/ gtopo30.asp. Accessed 2006 Oct 10.

Vargas JM. 2002. Alerta cinegética. Reflexiones sobre el futuro de la caza en España. Madrid: Otero.

Vargas JM, Muñoz AR. 1996. Panorámica de la caza menor en Andalucía. In: Federación Andaluza de Caza, editor, La caza en Andalucía y su problemática. Málaga: Federación Andaluza de Caza. pp 1-19.

Vargas JM, Farfán MA, Guerrero JC, Real R. 2004. Caracterización de los aprovechamientos cinegéticos a escala macroespacial: Un ejemplo aplicado a la provincia de Granada (sur de España). Ecología 18:53-70.

Vargas JM, Guerrero JC, Farfán MA, Barbosa AM, Real R. 2006. Land use and environmental factors affecting red-legged partridge (Alectoris rufa) hunting yields in Southern Spain. European Journal of Wildlife Research 52:188-195.

Vargas JM, Farfán MA, Guerrero JC, Barbosa AM, Real R. 2007. Geographical and environmental correlates of big and small game in Andalusia (southern Spain). Wildlife Research 34:498-506.

Villafuerte R. 2002. Oryctolagus cuniculus Linnaeus, 1758. In: Palomo LJ, Gisbert J, editors. Atlas de los mamíferos terrestres de España. Madrid: Dirección General de Conservación de la Naturaleza-SECEM-SECEMU. pp 464-467.

Villafuerte R, Calvete C, Blanco JC, Lucientes J. 1995. Incidence of viral hemorrhagic disease in wild rabbit populations in Spain. Mammalia 59:651-659.

Villafuerte R, Kufner MB, Delibes M, Moreno S. 1993. Environmental factors influencing the seasonal daily activity of the European rabbit (Oryctolagus cuniculus) in a Mediterranean area. Mammalia 57:341-347.

Villafuerte R, Lazo A, Moreno S. 1997. Influence of food abundance and quality on rabbit fluctuations: conservation and management implications in Doñana National Park (SW Spain). Révue d'Écologie (Terre et Vie) 52:345-356.

Villafuerte R, Viñuela J, Blanco JC. 1998. Extensive predator persecution caused by population crash in a game species: The case of red kites and rabbits in Spain. Biological Conservation 84:181-188.

Whittaker J. 1984. Model interpretation from the additive elements of the likelihood function. Applied Statistics 33:52-64. 